\title{
Process Characteristics of Horizontal Log Band Saw in Cutting Frozen Beech
}

\section{Obilježja procesa obrade na horizontalnoj tračnoj pili trupčari pri piljenju zamrznute bukovine}

\author{
Original scientific paper • Izvorni znanstveni rad \\ Received-prispjelo: 4. 4. 2014. \\ Accepted-prihvaćeno: 14. 1. 2015. \\ UDK: $630 * 822.341$ \\ doi:10.5552/drind.2015.1412
}

\begin{abstract}
The paper presents the research results of process characteristics during cutting beech prisms on horizontal log band saw type Mebor HTZ-1000. The band saw blades were equipped with swaged teeth and stellited teeth. The power consumption, tool wear resistance, surface roughness and variation of board thickness during $6000 \mathrm{~m}$ sawn prism length were studied. All studied parameters were monitored during the tool life-circle (from sharpening to loosing its sawing capability). Wearing process was monitored as a function of cutting length. The cutting edge modification, i.e. its wearing affecting energetic demands during sawing process as well as the surface quality and dimension accuracy of produced work piece was monitored, too.

Based on cutting edge wear process and its effect on the above mentioned sawing process parameters, the optimal period of saw band replacement with a new or sharpened one was determined. Based on measured parameters, it was possible to determine which type of band saw tooth is recommended for cutting frozen beech.
\end{abstract}

Key words: horizontal log band saw, band saw blade, stellite teeth, swaged teeth, cutting wedge wear, cutting power, surface quality

\begin{abstract}
SAŽETAK • U radu se iznose rezultati istraživanja obilježja procesa piljenja bukovih prizmi na horizontalnoj tračnoj pili trupčari proizvođača Mebor, model HTZ-1000. Za piljenje su primijenjeni listovi pila sa stlačenim i stelitiranim zubima. Proučavana je snaga potrebna za piljenje, postojanost alata, hrapavost obrađene plohe $i$ odstupanje debljine piljenica od nominalne dimenzije, i to tijekom piljenja prizmi ukupne duljine $6000 \mathrm{~m}$. Svi proučavani parametri praćeni su tijekom vremena postojanosti pojedinog lista pile. Proces trošenja zubi lista pile promatran je kao funkcija duljine puta zahvata tijekom piljenja. Također je analiziran utjecaj postupnog zatupljivanja zubi lista pile na energiju potrebnu za piljenje, na kvalitetu obrađene plohe i na odstupanje dimenzija piljenica s obzirom na nominalne vrijednosti.

Uzimajući u obzir proces zatupljivanja zubi lista pile i utjecaj na promatrane parametre obrade, određeno je optimalno vrijeme zamjene lista pile. Na temelju izmjerenih parametara zaključeno je koji je način pripreme zubi pile preporučljiv za piljenje zamrznute bukovine.
\end{abstract}

Ključne riječi: horizontalna tračna pila trupčara, list tračne pile, stelitirani zubi, stlačeni zubi, trošenje oštrice alata, snaga rezanja, kvaliteta obrađene plohe

\footnotetext{
${ }^{1}$ Authors are professor and assistants at Technical University of Zvolen, Faculty of Wood Technology, Zvolen, Zvolen, Slovak Republic. ${ }^{2}$ Authors are young researcher and assistant professor at University of Zagreb, Faculty of Forestry, Department of Wood Technology, Zagreb, Croatia.

${ }^{1}$ Autori su profesor i asistenti Tehničkog sveučilišta u Zvolenu, Fakultet drvne tehnologije, Zvolen, Republika Slovačka. ${ }^{2}$ Autori su znanstveni novak i docent Sveučilišta u Zagrebu, Šumarski fakultet, Drvnotehnološki odsjek, Zagreb, Hrvatska.
} 


\section{INTRODUCTION}

\section{UVOD}

Log band saw is one of the main sawmilling machines designed to saw leafy hardwood species with large diameters. Csanády et al. (2011) defined the sawing process on log band saw as wood splitting by evenly moving tool, during which feed force vector acts across the saw band. As it was presented by Detvaj (2003) and Siklienka (2006), it is an individual method of cutting, the principle of which is based upon qualitative and geometrical characteristics of hardwood logs (Gejdoš et al., 2014; Suchomel et al., 2010). These logs often require specific cutting layout during the sawing process. The advantage of band saws is that there is no need to classify and sort logs into large number of categories in regard to variance of log crosssection (Lisičan et al., 2000).

The sawing process on a log band saw is considerably influenced by numerous parameters. The season of the cutting process (summer/winter) also affects the process. Frozen wood changes its mechanical properties and it has different impact on the cutting tool. The consequence is the reduction of the dimensional accuracy of sawn products as well as production economics effects (Fryková et al., 2010). Frozen wood is more fragile than unfrozen wood and according to Lustrum (2001) and Gaff et al. (2010) there is less variance of surface unevenness due to lower saw band plate friction. Orlowský et al. (2006) as well as Fryková et al. (2010) allege that sawing frozen wood is energetically more demanding than sawing unfrozen wood.

In practice, it is very important to saw with minimal energetic input demands at the same time attempting to achieve the best output quality of sawing products. As mentioned by Wasilewski et al. (1999) and also Siklienka et al. (2005), suitable tool selection, tool geometry and cutting conditions can lower the costs of the cutting process and increase the performance and accuracy of cutting.

Surface quality of wooden sawing products is mostly characterized by their unevenness. Siklienka (2004) and Sandak et al. (2005) present 4 classes of surface unevenness: form variance, washboarding, roughness and micro-roughness.

During sawing on band saws, the quality of workpieces is monitored and evaluated on the basis of the surface unevenness parameter $\left(P_{\mathrm{z}}-\right.$ the difference between height mean value of five highest points and mean value of five lowest points of primary profile) in accordance to STN EN ISO 4287 and on the basis of deviation of trimmed layer thicknesses. Both parameters are monitored in dependence of the indicated chip length (ICL). This quality monitoring method was also used by Fryková et al. (2010) and Silienka et al. (2008, 2011).

The indicated chip length (ICL) is the tool effective edge trajectory through the workpiece during cutting. An important influencing factor that affects energy demands as well as the quality of cutting surface is the wear of the cutting edge. Wearing is caused by the resistance of the machined material (Očkajová, 2002).
This resistance is based on wood stiffness, bend deformation, chip friction on teeth cutting face and friction of the teeth back as well as machined surface (Hájnik et al., 2008).

The aim of this article is to describe the effect of cutting wedge wearing on energy demands and qualitative indicators of the sawing process by sawing frozen beech prisms on horizontal log band saw type Mebor HTZ-1000. The practical result of this article are references that should enable choosing the suitable saw band plate in accordance with the cutting wedge wear, cutting process energy demands and the quality of machined surface.

\section{MATERIAL AND METHODS}

\section{MATERIJAL I METODE}

The sawing of beech prisms was carried out on horizontal log band saw type Mebor HTZ-1000 (Fig. 1), installed in VDL TU in Zvolen.

Technical data:

- wheel diameter: $D=1000 \mathrm{~mm}$,

- band blade width: $B=95 \mathrm{~mm}$,

- cutting speed: $v_{\mathrm{c}}=30 \mathrm{~m} \cdot \mathrm{s}^{-1}$,

feed rate: $v_{\mathrm{f}}=(0 \div 40) \mathrm{m} \cdot \mathrm{min}^{-1}$ (adjustable)

max. log diamater: $800 \mathrm{~mm}$,

- main electromotor output power: $P_{\mathrm{EM}}=22 \mathrm{~kW}$.

\subsection{Characteristics of sample work pieces}

2.1. Parametri uzoraka

Beech prisms - European beech (Fagus sylvatica L.) were used for the experimental measurement. The prisms humidity was over the point of fibers saturation, in the range $(53 \div 56) \%$. The logs were transported from the Budča area - provided by the University forest enterprise (ŠLP) TU Zvolen. The cutting of beech prisms was done under the following conditions:

- feed rate $v_{\mathrm{f}}=10 \mathrm{~m} \cdot \mathrm{min}^{-1}$,

- cutting height $h=300 \mathrm{~mm}$,

- band saw blade with stellited teeth and band saw blade with swaged teeth

- thickness of trimmed sample $=3 \mathrm{~mm}$

- frozen prisms - prisms were placed in ambient temperature $-15^{\circ} \mathrm{C}$ for at least 48 hours.

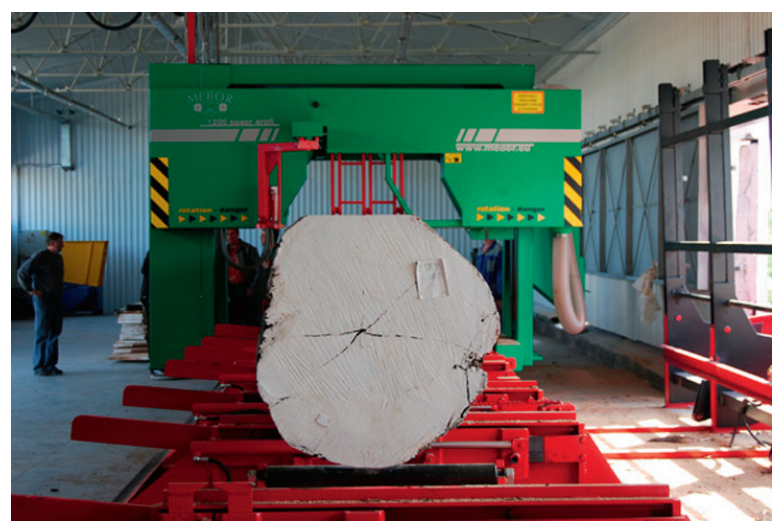

Figure 1 Horizontal log band saw Mebor HTŽ -1000

Slika 1. Horizontalna tračna pila trupčara Mebor HTŽ-1000 
...... Siklienka, Kminiak, Argay, Šafran, Đukić: Process Characteristics of Horizontal Log...

Table 1 Geometry parameters of the band saw blade

Tablica 1. Geometrijski parametri lista tračne pile

\begin{tabular}{|c|c|c|c|c|c|}
\hline $\begin{array}{l}\text { Parameter } \\
\text { Parametar }\end{array}$ & $\begin{array}{c}\text { Symbol } \\
\text { Simbol }\end{array}$ & $\begin{array}{c}\text { Value } \\
\text { Vrijednost }\end{array}$ & $\begin{array}{l}\text { Parameter } \\
\text { Parametar }\end{array}$ & \begin{tabular}{|c} 
Symbol \\
Simbol
\end{tabular} & $\begin{array}{c}\text { Value } \\
\text { Vrijednost }\end{array}$ \\
\hline Clearance angle, $^{\circ} /$ leđni $k u t,{ }^{\circ}$ & $\alpha$ & 15 & Blade thickness, $\mathrm{mm} /$ debljina lista, $\mathrm{mm}$ & $a$ & 1.1 \\
\hline Sharpness angle, ${ }^{\circ} /$ kut oštrice, $^{\circ}$ & $\beta$ & 50 & Tooth height, $\mathrm{mm} /$ visina zuba, $\mathrm{mm}$ & $h_{\mathrm{z}}$ & 10 \\
\hline Rake angle, ${ }^{\circ} /$ prednji kut, ${ }^{\circ}$ & $\gamma$ & 25 & Tooth spacing, mm / korak zuba, $\mathrm{mm}$ & $t_{\mathrm{z}}$ & 45 \\
\hline Cutting angle, ${ }^{\circ} /$ kut rezanja, $^{\circ}$ & $\delta$ & 65 & Swage set, $\mathrm{mm} /$ ispon zuba, $\mathrm{mm}$ & $e$ & $0.35 \pm 0.05$ \\
\hline Band width, mm / širina lista, $\mathrm{mm}$ & $B$ & 100 & & & \\
\hline
\end{tabular}

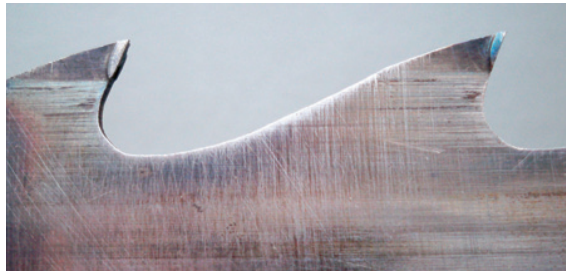

a)

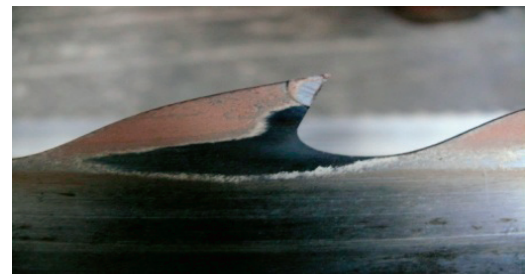

b)

Figure 2 Swaged tooth a), and tooth with stellite b) used in experimental cutting

Slika 2. Detalj listova pila primijenjenih u eksperimentu: a) sa stlačenim zubima i b) sa stelitiranim zubima

\subsection{Saw band characteristics}

\subsection{Parametri lista pile}

For the purpose of the experiment, band saw blades made by UHB 15 (Uddeholm, 2000) with hardness 38 - 44 HRc, supplied by KLI Produkt s.r.o were used. Geometry parameters of band saw blades (PP) are shown in Table 1 for both types of teeth.

Band saw blade with a swaged, i.e. a stellited tooth used in experimental cutting are shown in Fig. 2.

\subsection{The experiment procedure}

2.3. Tijek eksperimenta

At the beginning of the experiment, the initial cutting wedge wear on the band saw blade with sharpened swaged teeth was measured. Two initial cuts with sharpened saw band were made. Samples for the unevenness test were removed and at the same time the input cutting power was measured. The cutting was performed with the same band saw blade up to $50 \mathrm{~m}$ ICL. The samples for the unevenness test were removed periodically. Before that, input cutting power and cutting wedge wear were measured. This testing procedure was repeated every $500 \mathrm{~m} \mathrm{ICL}$ until the machined surface has shown defects of quality visible with the naked eye. The same test procedure was applied for both types of teeth.

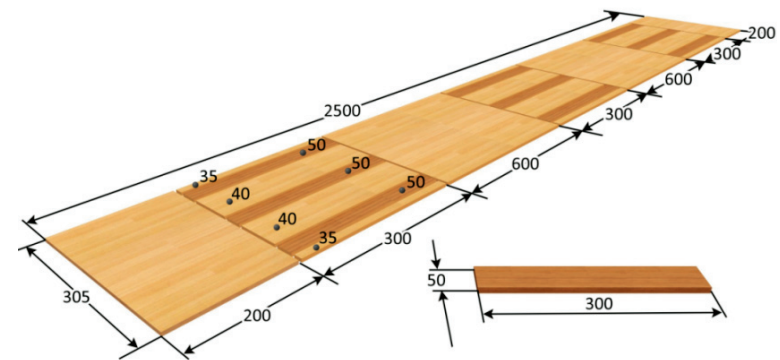

Figure 3 Sample selection for surface unevenness measurement

Slika 3. Shema uzimanja uzoraka od piljenica za određivanje kvalitete obrađene plohe
Surface unevenness was measured on samples of 300x50x3 mm. The samples were cut-out following the cutting layout shown in Fig. 3.

The surface unevenness was measured with a laser measuring equipment, Type LPM-4, which was assembled and installed at the Department of Woodworking at the Technical University in Zvolen in cooperation with the Kvant Ltd. Company. The measuring chain (Fig. 4) was assembled of the following components: a profile meter LPM-4 was installed on the height adjustable console; the recording and evaluation unit was equipped with a LPM-View software. LPM uses the triangulation principle of laser profile meter. The image of the laser line was scanned with a digital camera. The interpreted profile was scanned from the image cross section (Siklienka et al., 2001). The principle of the laser profile meter is shown in Figure 5.

Surface unevenness was evaluated according to the actual woodworking standard STN EN ISO 4288 on the length of $80 \mathrm{~mm}$. The surface unevenness of the tested specimen was measured in feed speed direction during cutting. The surface unevenness was evaluated based on the maximum height of primary profile $P_{\mathrm{z}}$.

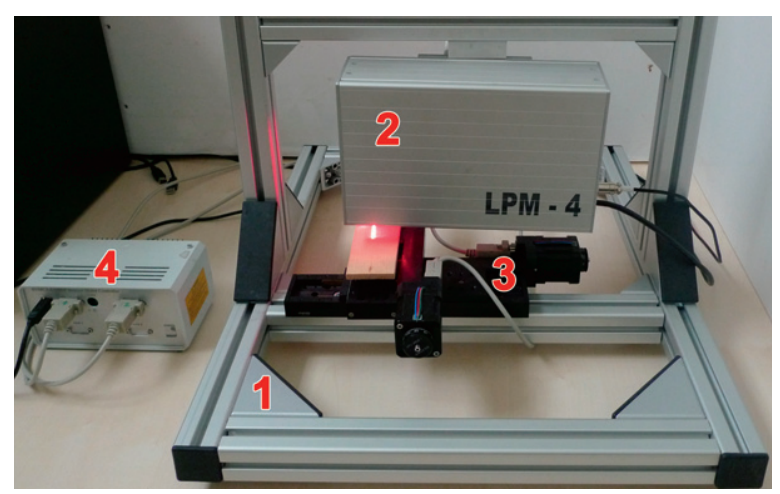

Figure 4 Surface roughness measuring chain Slika 4. Mjerni lanac za određivanje hrapavosti piljene plohe 


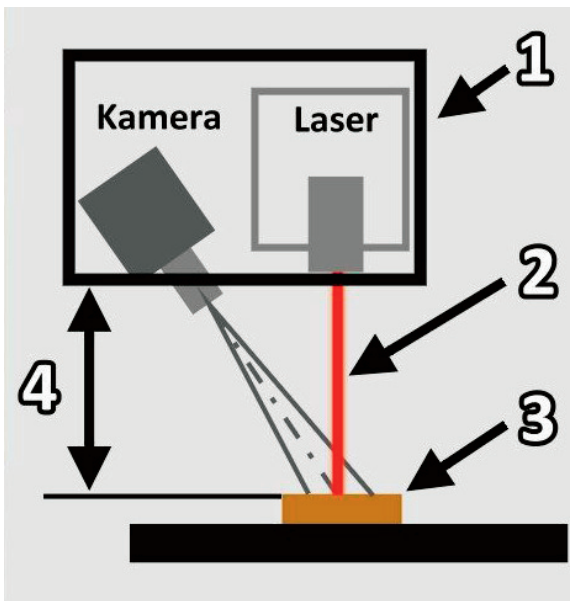

Figure 5 Principle of laser profile meter LPM 4 (1 - camera, 2 - laser, 3 - tested specimen, 4 - distance between LPM and measured object)

Slika 5. Shematski prikaz načela mjerenja uz pomoć laserskog profilometra LPM 4 (1-kamera, 2 - laser, 3 uzorak, 4 - udaljenost između lasera i mjernog objekta)

Cutting input power was measured using the measuring device designed for analyzing the electrical power network quality. The Metrel Power Q Plus MI 2392 device was installed into the electric network before connecting the separate phases into the main machine electromotor.

The measuring principle was based on the changes of power demand of the main electromotor of the log band saw from the power network (Siklienka et al., 2011). For the calculation of the electromotor input power, the Metrel Power Q scans the changes of current demand $(I)$, actual voltage $(U)$ and power factor $(\cos \varphi)$. The values were recorded in intervals of $1 \mathrm{sec}-$ ond. All values were measured with the frequency of $1024 \mathrm{~Hz}$. The measuring values were averaged in periods of 1 second. These averaged values were the base for the power consumption evaluation. The power measuring device was connected to the computer via RS 232 interface. Values were downloaded with the Power Q Link 2.1 software (Hajník, 2008).

Cutting wedge wear was measured using microscopic method based on measuring the increase of cutting edge radius $\left(r_{\mathrm{n}}\right)$. The increase of the wedge radius is a consequence of cutting during certain effective

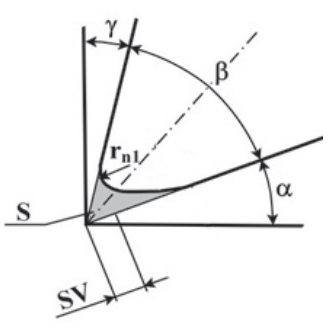

a)

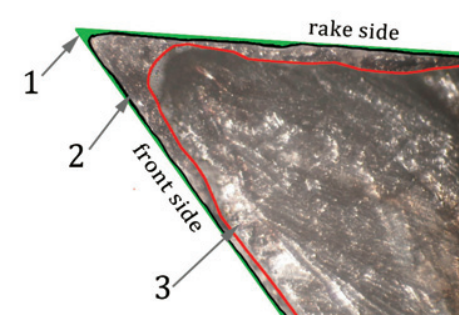

b) time (Fig. 6). The measurements were carried out according to the internal methodology at the Department of Woodworking at the Technical University in Zvolen. As Hajník et al. (2008) stated, it is a method of evaluation with the help of a digital camera and a microscope. Digital photography of the cutting wedge (Fig. 6/c) is graphically analyzed using AutoCAD software.

\section{RESULTS AND DISCUSSION}

3. REZULTATI I RASPRAVA

\subsection{Cutting wedge radius}

3.1. Radijus zaobljenosti oštrice

Increase of the cutting wedge radius of saw bands swaged teeth and stellited teeth at sawing frozen beech prisms are given in Table 2.

The data obtained with the experimental cutting given in Table 3 were analyzed and fitted with the polinomal regression. The results are shown in Fig. 7a) and $7 \mathrm{~b})$.

Stellited teeth have shown evidently higher wear resistence in comparison with swaged teeth in cutting frozen beech prisms. Catastrophic wear was observed on swaged teeth after cutting length of $2500 \mathrm{~m}$. In the

Table 2 Change of the cutting wedge radius during cutting for swaged teeth and stellited teeth as a function of cutting length

Tablica 2. Promjena radijusa zaobljenosti oštrice za stlačene i stelitirane zube kao funkcija duljine puta zahvata

\begin{tabular}{|c|c|c|}
\hline \multirow{2}{*}{ ICL, $\mathbf{m}$} & \multicolumn{2}{|c|}{$\begin{array}{c}\text { Cutting wedge radius, } \mu \mathbf{m} \\
\text { Radijus zaobljenosti oštrice, } \mu \mathrm{m}\end{array}$} \\
\cline { 2 - 3 } & $\begin{array}{c}\text { Swaged teeth } \\
\text { Stlačeni zubi }\end{array}$ & $\begin{array}{c}\text { Stellited teeth } \\
\text { Stelitirani zubi }\end{array}$ \\
\hline 0 & 17 & 13 \\
\hline 500 & 53 & 33 \\
\hline 1000 & 63 & 52 \\
\hline 1500 & 70 & 64 \\
\hline 2000 & 79 & 74 \\
\hline 2500 & 89 & 85 \\
\hline 3000 & - & 85 \\
\hline 3500 & - & 88 \\
\hline 4000 & - & 91 \\
\hline 4500 & - & 91 \\
\hline 5000 & - & 100 \\
\hline
\end{tabular}

Figure 6 a) Wear of cutting edge (SV), b) real wear of cutting wedge, c) measuring apparatus for measuring SV with microscopic method

Slika 6. a) Trošenje rezne oštrice (SV), b) prikaz stvarnog trošenja oštrice i c) mjerni lanac za određivanje zatupljenosti oštrice uz pomoć mikroskopa 


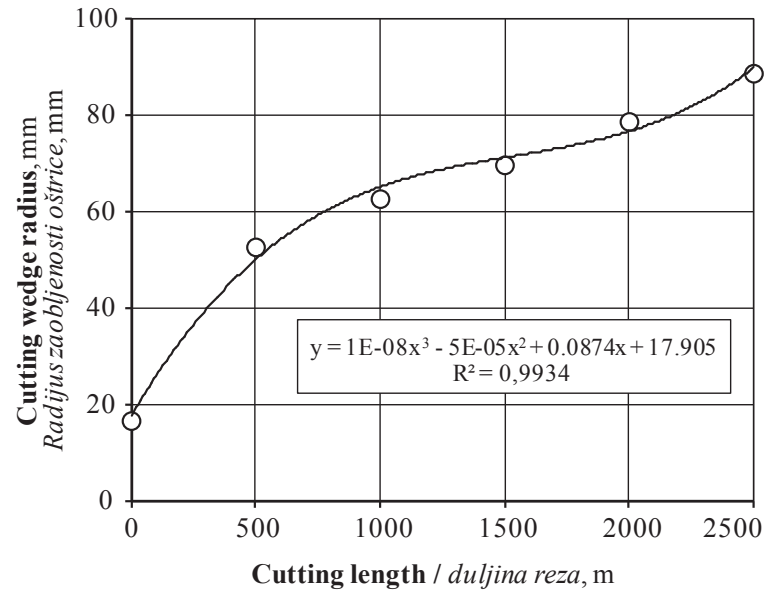

a)

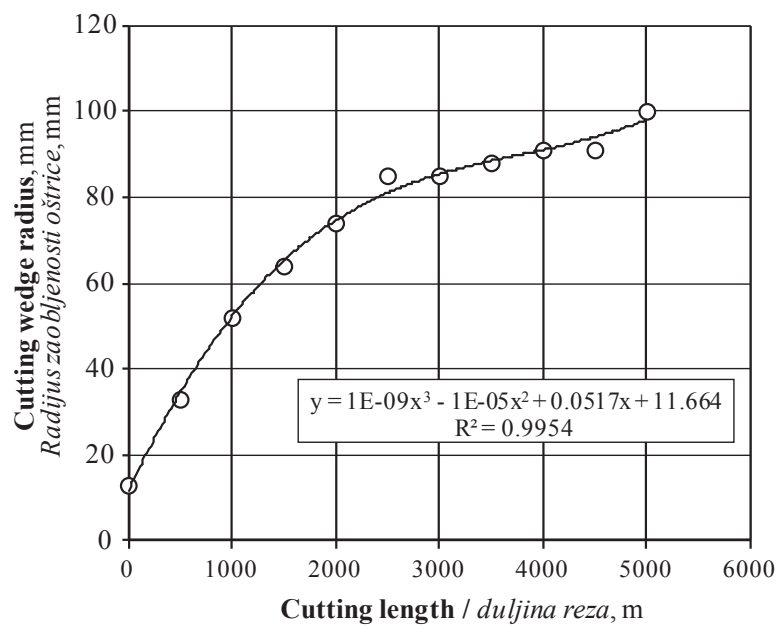

b)

Figure 7 Cutting wedge radius in relation to cutting length: a) swaged teeth and b) stellited teeth

Slika 7. Promjena radijusa zaobljenosti oštrice kao funkcija duljine puta zahvata: a) za stlačene zube i b) za stelitirane zube pile

same cutting conditions, catastrophic wear was observed on the stellited teeth at the double cutting length as clearly shown in Fig. 7 a) and 7 b). Vasilka et al. (2009) came to the same conclusion. The increase of the radius of the cutting wedge as a result of the ICL increase was also confirmed in the works of Lisičan et al. (1996), Očkajová (2001), Javorek et al. (2006) and Siklienka et al. (2007).

\subsection{Cutting input power}

\subsection{Snaga rezanja}

Cutting power was measured periodically in the same intervals as tool wedge radius during cutting with the swaged teeth and stelitted teeth. The results obtained during power measurements are given in Table 3 . The data for cutting with swaged teeth are graphically presented in Fig. 8 a), and for cutting with stellited teeth in Fig. 8 b).

Fig. 8 a) cleary shows that the power required for cutting frozen beech prisms with sharpened teeth intensively increases at the start until approximately $1000 \mathrm{~m}$ of cutting length. After that, the power con-

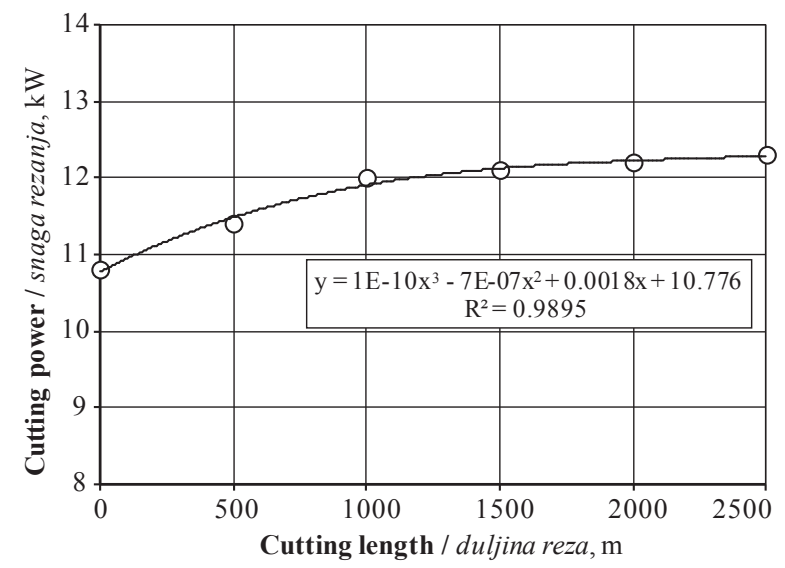

a)
Table 3 Power consumption in cutting frozen beech prism with swaged and stellited teeth

Tablica 3. Snaga potrebna za piljenje bukovih prizmi primjenom lista pile: a) sa stlačenim zubma i b) sa stelitiranim zubima

\begin{tabular}{|c|c|c|}
\hline \multirow{2}{*}{ ICL, m } & \multicolumn{2}{|c|}{$\begin{array}{c}\text { Power consumption, } \mathbf{k W} \\
\text { Snaga piljenja, } \mathrm{kW}\end{array}$} \\
\cline { 2 - 3 } & $\begin{array}{c}\text { Swaged teeth } \\
\text { Stlačeni zubi }\end{array}$ & $\begin{array}{c}\text { Stellited teeth } \\
\text { Stelitirani zubi }\end{array}$ \\
\hline 0 & 10.8 & 10.2 \\
\hline 500 & 11.4 & 10.9 \\
\hline 1000 & 12.0 & 12.1 \\
\hline 1500 & 12.1 & 12.5 \\
\hline 2000 & 12.2 & 13.0 \\
\hline 2500 & 12.3 & 13.8 \\
\hline 3000 & - & 13.9 \\
\hline 3500 & - & 14.0 \\
\hline 4000 & - & 14.7 \\
\hline 4500 & - & 16.1 \\
\hline 5000 & - & 17.2 \\
\hline
\end{tabular}

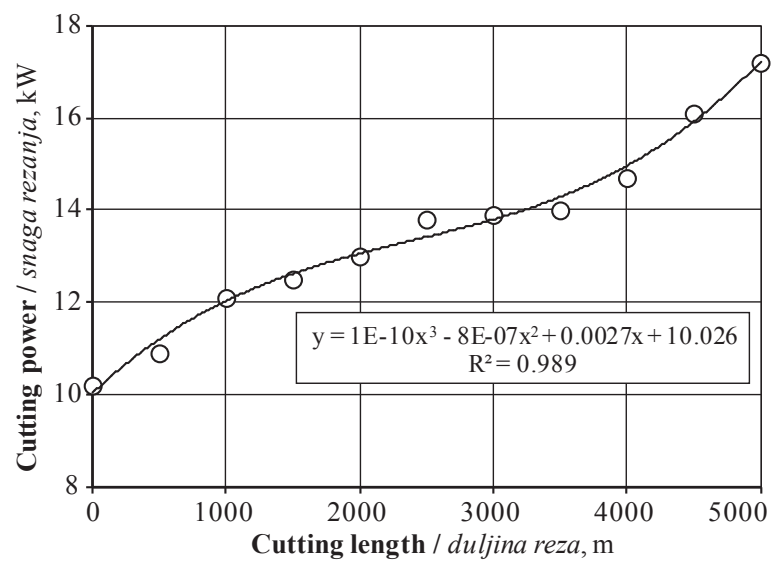

b)

Figure 8 Power consumption during sawing frozen prisms in relation to total cutting lenght: a) swaged teeth, and b) stellited teeth

Slika 8. Snaga potrebna za piljenje zamrznutih prizmi u ovisnosti o ukupnoj duljini piljenja: a) za stlačene zube i b) za stelitirane zube 
sumption increases lineary until the period in which catastrophic tool wear occurs. The power consumption curve follows the changes of the tool wedge radius over the whole interval of cutting length. The same comment applies to the changes in the level of power consumption in different periods when cutting with stellited teeth. It corresponds to the conclusion of Javorek (1995) and Holopírek (2004), who state that the cutting power input increases with the increase of the cutting surface, cutting time and cutting wedge wear. Similar trends were presented in the works of Siklienka et al. (2011) and Hajník (2008).

\subsection{Sawing surface quality}

\subsection{Kvaliteta obrađene plohe}

The tool influence on the cutting surface quality is usually evaluated by measuring surface roughness, i.e. maximum height of the primary profile $\left(P_{\mathrm{z}}\right)$. Another quality indicator, called thickness deviation, was also used in this study.

a) Surface roughness

The data obtained in measuring surface roughness are given in Table 4 . The surface roughness was measured at the same time intervals as the increase of tool wedge radius and power consumption. The surface roughness in relation to cutting length for swaged teeth is graphically presented in Fig. 9a). The relation between the surface roughness and cutting length for stellited teeth is shown in Fig. 9b). The data obtained in measuring the surface roughness were statistically analyzed and fitted with linear equations. The results are also given in Fig. 9a) and b). The regression coefficients show very strong correlation between surface roughness and cutting length.

From the point of view of the machined surface quality (Table 5, Fig. 9a) and b)), it is obvious that sawing frozen beech prism using stellite tipped band saw blades leads to better surface quality. This observation corresponds with Okai's et al. (2006) and Lustruma's (2001) research results. The surface roughness measurement has shown that roughness of machined surface increases with the increase of cutting length as a

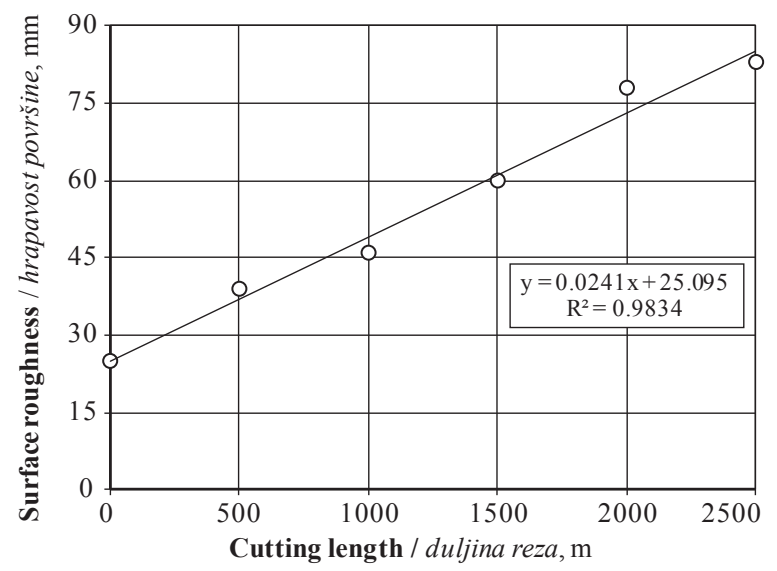

a)
Table 4 Machined surface quality in cutting frozen beech prism with swaged and stellited teeth

Tablica 4. Kvaliteta obrađene plohe nakon piljenja zamrznutih prizmi od bukovine uz pomoć lista pile sa stlačenim i sa stelitiranim zubima

\begin{tabular}{|c|c|c|}
\hline \multirow{2}{*}{ ICL, $\mathbf{m}$} & \multicolumn{2}{|c|}{$\begin{array}{c}\text { Surface roughness, } \mu \mathbf{m} \\
\text { Hrapavost površine, } \mu \mathrm{m}\end{array}$} \\
\cline { 2 - 3 } & $\begin{array}{c}\text { Swaged teeth } \\
\text { Stlačeni zubi }\end{array}$ & $\begin{array}{c}\text { Stellited teeth } \\
\text { Stelitirani zubi }\end{array}$ \\
\hline 0 & 25 & 24 \\
\hline 500 & 39 & 40 \\
\hline 1000 & 46 & 47 \\
\hline 1500 & 60 & 52 \\
\hline 2000 & 78 & 54 \\
\hline 2500 & 83 & 73 \\
\hline 3000 & - & 80 \\
\hline 3500 & - & 82 \\
\hline 4000 & - & 94 \\
\hline 4500 & - & 102 \\
\hline 5000 & - & 104 \\
\hline
\end{tabular}

result of cutting wedge wear (Table 3). The same conclusion was reached by Siklienka (2004), Wilkowski et al. (2006) and Carpa et al. (2006).

b) Thickness deviation

Table 5 shows the results of measurement of thickness deviations. The data are graphically presented in Fig. 10 a) and b). The data obtained by measurement were analyzed with the help of mathematical statistics and fitted with polynomial curves. The results are also shown in Fig. 10 a) and b).

Fig. 10 clearly shows that the height deviation is greater in samples sawed with the swaged teeth. The increase of the height deviation ratio on the surfaces sawed with swaged teeth is very intensive in the cutting length interval from the start to approximately $1300 \mathrm{~m}$ and nearly constant in the interval from 1300 $\mathrm{m}$ to $2300 \mathrm{~m}$. After that period, the height deviation dramatically increases. The $4^{\text {th }}$ degree polynomial regression very well fits the changes of the height increase of the surface sawn with swaged teeth with a very high correlation coefficient. The height deviations

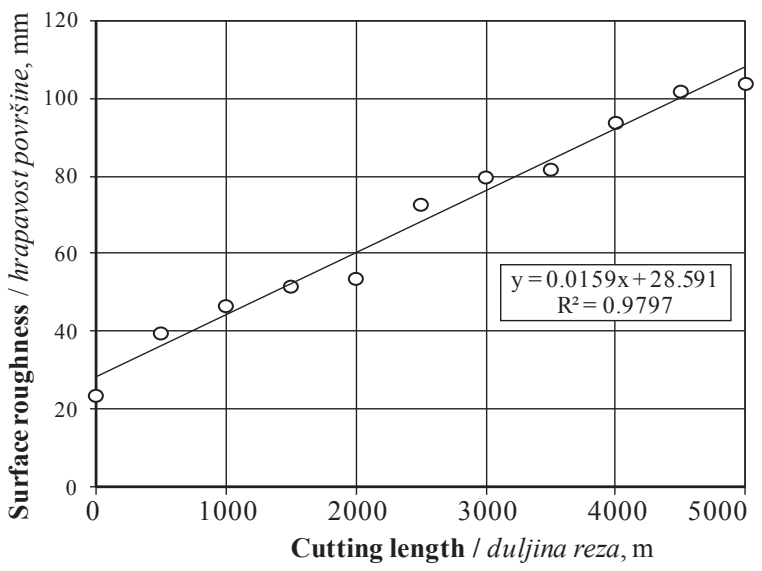

b)

Figure 9 Surface roughness during sawing frozen prisms in relation to total cutting lenght: a) swaged teeth and b) stellited teeth

Slika 9. Ovisnost hrapavosti obrađene plohe pri piljenju zamrznutih bukovih prizmi o ukupnoj duljini puta zahvata: a) za stlačene zube i b) za stelitirane zube 


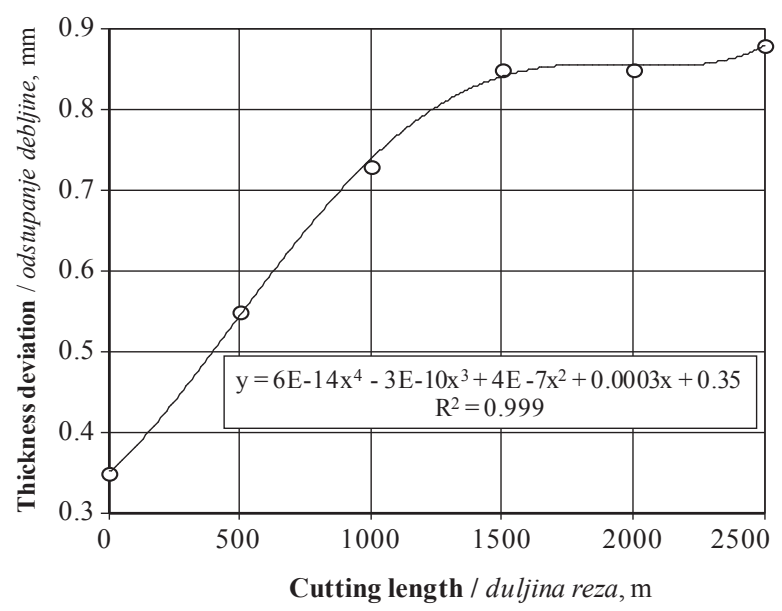

a)

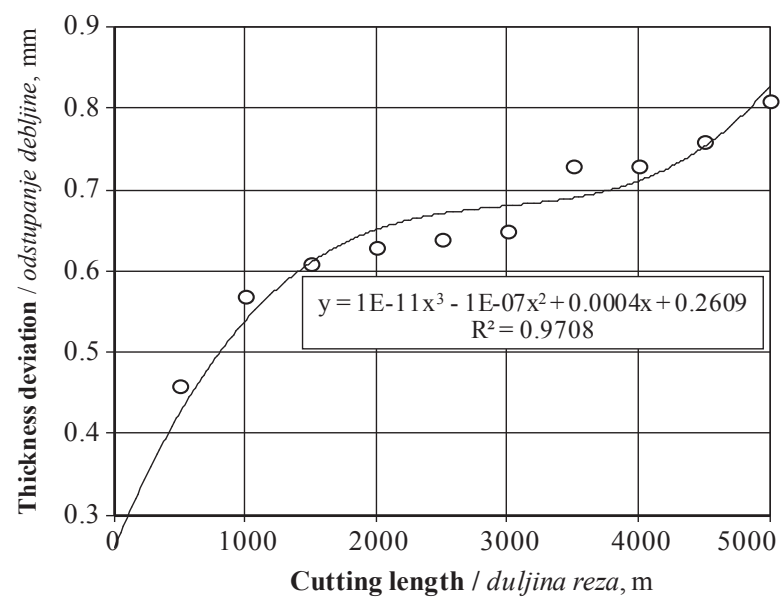

b)

Figure 10 Thickness deviation of the surface in relation to cutting length: a) for swaged teeth, b) for stellited teeth Slika 10. Promjena odstupanja debljine ispiljenih uzoraka od nominalne dimenzije s obzirom na duljinu puta zahvata alata: a) za stlačene zube i b) za stelitirane zube

Table 5 Surface height deviation in cutting frozen beech prism with swaged and stellited teeth

Tablica 5. Odstupanje debljine ispiljenih uzoraka od nominalne dimenzije pri piljenju zamrznutih bukovih prizmi primjenom lista pile sa stlačenim i sa stelitiranim zubima

\begin{tabular}{|c|c|c|}
\hline \multirow{2}{*}{ ICL, $\mathbf{m}$} & \multicolumn{2}{|c|}{$\begin{array}{c}\text { Thickness deviation, } \mathbf{~ m m} \\
\text { Odstupanje debljine, } \mathrm{mm}\end{array}$} \\
\cline { 2 - 3 } & $\begin{array}{c}\text { Swaged teeth } \\
\text { Stlačeni zubi }\end{array}$ & $\begin{array}{c}\text { Stellited teeth } \\
\text { Stelitirani zubi }\end{array}$ \\
\hline 0 & 0.35 & 0.23 \\
\hline 500 & 0.55 & 0.46 \\
\hline 1000 & 0.73 & 0.57 \\
\hline 1500 & 0.85 & 0.61 \\
\hline 2000 & 0.85 & 0.63 \\
\hline 2500 & 0.88 & 0.64 \\
\hline 3000 & & 0.65 \\
\hline 3500 & & 0.73 \\
\hline 4000 & & 0.73 \\
\hline 4500 & & 0.76 \\
\hline 5000 & & 0.81 \\
\hline
\end{tabular}

of the surfaces sawn with stellited teeth are significantly lower. The intensive increase of height deviation could be viewed in the interval from the start to 2000 $\mathrm{m}$. After that the increase ratio is approximately linear until $4000 \mathrm{~m}$ of cutting length. Finally, in the last section from $4000 \mathrm{~m}$ to $5000 \mathrm{~m}$, the surface height deviation drastically increases. The changes in surface height deviation in relation to cutting length were fitted with the $3^{\text {rd }}$ degree polynomial regression with very high correlation coefficient as shown in Fig. 10.

\section{CONCLUSION}

\section{ZAKLJUČAK}

Sawing frozen beech prisms on the horizontal band saw with swaged and stelitted teeth has shown some interesting results. The following conclusions could be drawn:

- Stellited teeth have shown significantly higher wear resistance in comparison to swaged teeth. Catastrophic wear was observed on swaged teeth after
$2500 \mathrm{~m}$ of sawing length. The stellited teeth have shown near double wear resistance. The catastrophic wear was observed after approximately $4800 \mathrm{~m}$ of cutting length

- According to the wear characteristics of the two different types of teeth, the power consumption during tool life period has not shown the expected results. Power consumption during the first $2500 \mathrm{~m}$ of cutting length was comparable for both types of teeth. After that period, due to the unacceptable quality of the cutting surface, cutting with the swaged teeth was stopped.

- During sawing with the swaged teeth, the surface roughness has increased to the unacceptable level after $2500 \mathrm{~m}$. That was the reason why cutting has been stopped. Quite the opposite, the surface quality with stellited teeth remained acceptable until $5000 \mathrm{~m}$ of cutting length.

- The results of measurement of sample height deviation are the same. The increase of height deviation ratio on the surfaces sawed with swaged teeth is very intensive in the cutting length interval from the start to approximately $1300 \mathrm{~m}$ and nearly constant in the interval from $1300 \mathrm{~m}$ to $2300 \mathrm{~m}$. After that period, the height deviation dramatically increases. Height deviation of the surfaces sawn with stellited teeth is significantly lower. Intensive increase of height deviation could be observed in the interval from the start to $2000 \mathrm{~m}$. After that, the increase ratio is approximately linear until $4000 \mathrm{~m}$ of cutting length. Finally, in the last period from $4000 \mathrm{~m}$ to $5000 \mathrm{~m}$, the surface height deviation drastically increases.

\section{REFERENCES}

5. LITERATURA

1. Barcík, Š.; Kminiak, R.; Řehák, T.; Kvietková, M., 2010: The influence of selected factors on energy requirements for plain milling of beech wood. Journal of forest science, 56(5): 243-250.

2. Carp, C.; Badescu, L. A., 2006: The evolution of tools wearing and surface quality during MDF milling. Medzinárodná vedecká konferencia $\mathrm{k} 10$. výročiu vzniku 
FEVT. Trendy lesníckej, drevárskej a environmentálnej techniky a jej aplikácie vo výrobnom procese. Zvolen, 5 - 7, September 2006, pp. 48-56.

3. Csanády, E.; Magoss, E., 2011: Mechanics of wood machining. Sopron: Department of wood engineering, pp. 241-243.

4. Detvaj, J., 2003: Technológia piliarskej výroby. Zvolen, Technická univerzita vo Zvolene, pp. 112-115.

5. Fryková, D., 2010: Vplyv vybraných faktorov na rezný proces zmrznutého bukového dreva na kmeňovej pásovej píle, (dizertačná práca). Zvolen, Technická univerzita vo Zvolene.

6. Fryková, D.; Siklienka, M., 2010: Vplyv vybraných faktorov na nerovnost' povrchu pri pílení zmrznutého bukového dreva. Trieskové a beztrieskové obrábanie dreva, 9 - 11 September 2010. Terchová, pp. 77-84.

7. Gejdoš, M.; Suchomel, J.; Potkány, M., 2014: Software "Image J" application in evaluating the quality of extracted raw wood assortments. Drvna industrija, 65(2).

8. Hájnik, I., 2008: Vplyv vybraných technicko-technologických parametrov na kvalitu pílenia bukového dreva na kmeňovej pásovej píle, (dizertačná práca). Zvolen. Technická univerzita vo Zvolene.

9. Hájnik, I.; Fryková, D., 2008: Vplyv použitého pílového pásu na opotrebenie rezného klina pri pílení bukových priziem na kmeňovej pásovej píle. Trieskové a beztrieskové obrábanie dreva, 11 - 13 September 2008. Štúrovo, pp. 99-111.

10. Holopírek, J., 2004: Comparison of the theoretical calculation of resistance in cutting particleboards with an experiment. Trieskové a beztrieskové obrábanie dreva ' 04 . Zborník prednášok, 14 -16 October, Starý Smokovec, pp. 99-104.

11. Javorek, L', 1995: Rezný výkon - teória a prax. In: Problematika spracovania dreva, nové technológie, strojné zariadenia, Zborník prednášok Dom techniky ZS VTS Žilina, pp. 120-126.

12. Javorek, L'; Nováček, E., 2005: Rezný klin - opotrebovanie a optimalizácia. Acta Facultatis Xylologiae, Zvolen, 7(1): 52-55.

13. Jurko, J. et al., 2005: Opotrebovanie rezných nástrojov. MM Prumyslové spektrum, 4: 34.

14. Lisičan, J.,1996: Teória a technika spracovania dreva. Zvolen, MATCENTRUM.

15. Lisičan, J.; Banský, M., 2000: Špecifické problémy spracovania drevnej suroviny na rezivo. Vedecké štúdie. Technická univerzita Zvolen.

16. Lustrum, S., 2001: Balanced saw performance - Part 1. Alaska wood products bulletin. A Service of the Juneau Economic Development Council, Wood Product Development Service.

17. Mádl, J., 1990: Teórie obrábení. Praha, ES ČVUT.

18. Molitor, M., 2010: Vplyv vybraných technicko-technologických parametrov na energetickú náročnost' a rozmerovú presnost' a kvalitu povrchu pri pílení rastlého dreva na horizontálnej kmeňovej pásovej píle (dizertačná práca). Zvolen. Technická univerzita vo Zvolene.

19. Očkajová, A., 2001: Opotrebenie rezného klina. Zborník referátov $\mathrm{z}$ odborného seminára Drevorezné nástroje Zvolen, pp. 21-25.

20. Okai, R.; Tanaka, C.; Ohtani, T.; Iwasak, Y., 2005: Application of a novel technique for band sawing using a tip-inserted saw regarding surface profiles. Holz als Rohund Werkstoff, 63: 256-265. http://dx.doi.org/10.1007/s00107-005-0023-6

21. Okai, R.; Tanaka, C.; Iwasaki, Y., 2006: Influence of mechanical properties and mineral salts in wood species on tool wear of high-speed steels and stellite-tipped tools -
Consideration of tool wear of the newly developed tipinserted band saw. Holz als Roh-und Werkstoff, 64: 4552. http://dx.doi.org/10.1007/s00107-005-0015-6

22. Sandak, J.; negri, m., 2005: Woodsurface roughness what is it. Proceedings of the 17th International Wood Machining Seminar, Rosenheim, 1: 242-250.

23. Siklienka, M., 2004: Vplyv vybraných faktorov na kvalitatívne ukazovatele pri pílení na kmeňovej pásovej píle. Zvolen, Vedecké štúdie 1/2004/A, 82 p.

24. Siklienka, M., 2006: Výtlačné valivé vedenie ako prostriedok zvýšenia tuhosti pílového pásu. 8. medzinárodná konferencia TRANSFER 2006: Fakulta špeciálnej techniky, Trenčianska univerzita Alexandra Dubčeka., Trenčín, pp. 503-503.

25. Siklienka, M.; Mišura, L', 2005: Vplyv presahu pílového kotúča a rýchlosti posuvu na rezný výkon. Zborník prednášok 7. medzinárodnej vedeckej konferencie Transfer 2005, Trenčín, pp. 464 -467.

26. Siklienka, M.; mišura, L'; Hajník, I., 2007: Characteristic of the tool wear during changing clearance in cutting by circular saw blade. Nove tehnologije i materijali u industrijama baziranim na sektoru šumarstva, Croatia, pp. 112-135.

27. Siklienka, M.; Šustek, J.; Hájnik, I., 2008: Kvantifikácia nerovností povrchu s využitím laserového profilometra pri pílení na horizontálnej pásovej píle. Trieskové a beztrieskové obrábanie dreva, Štúrovo, pp. 207-212.

28. Siklienka, M.; Molitor, M., 2011: Impact of selected technical - technological parameters on energy consumption sawing soft and hard wood. Proceedings of the 4th International Scientific Conference WOODWORKING TECHNIQUES, Prague, pp. 576-578.

29. Suchomel, J.; Gejdoš, M., 2010: Vplyv vybraných faktorov na výskyt nepravého jadra v drevine buk lesný (Fagus sylvatica). Acta Facultatis Xylologiae Zvolen, 52(1): 5-13.

30. Šustek, J.; Siklienka, M., 2012: Effect of saw blade overlap setting on the cutting wedge wear. Acta Facultatis Xylologiae, 54(1): 52-55.

31. Wasielewski, R.; Orlowski, K.; Blacharski, W., 1999: Frame sawing machines - kinematics and cutting force. Proceedings of the 14th International Wood Machining Seminar, pp. 819-825.

32. Wilkowski, J.; Górski, J., 2006: The influence of cutting edge wear on the quality of machined surface during the milling of wood based materials. Medzinárodná vedecká konferencia k 10. výročiu vzniku FEVT - Trendy lesníckej, drevárskej a environmentálnej techniky a jej aplikácie vo výrobnom procese. Zvolen, pp. 66-78.

33. *** STN ISO $3002-4$ 1995. Rezné nástroje. Základné veličiny pri rezaní a brúsení. 4. čast': Sily, práca a výkon. ÚNM Praha, 3-4.

34. *** STN EN ISO 4287 - 1999. Geometrické špecifikácie výrobkov (GPS). Charakter povrchu: Profilová metóda - Termíny, definície a parametre charakteru povrchu. SÚTN Bratislava: $28 \mathrm{p}$.

35. *** STN EN ISO $4288-2000$. Geometrické špecifikácie výrobkov (GPS). Charakter povrchu. Profilová metóda Pravidlá a postupy pri posudzovaní charakteru povrchu. SÚTN Bratislava:15 p.

\section{Corresponding address:}

Assist. Prof. IGOR ĐUKIĆ, Ph. D.

Faculty of Forestry

University of Zagreb

Svetošimunska 25

10000 Zagreb, CROATIA

e-mail: i_dukic@yahoo.com 